\title{
"An Unholy Alliance": Irish-Americans and the Political Construction of Whiteness in Memphis, Tennessee, 1866-1879
}

\section{Brian D. Page}

"Why this cry of nationality and race?" the Memphis Daily Appeal lamented, as the city prepared for the impending municipal election to occur on 2 January, 1874. Despite Redemption in Tennessee in 1870, Memphis conservatives were unable to control the local political scene. A cross-racial alliance composed of voting constituents from the Irish and African American, and to some extent German, communities formed a powerful voting bloc dictating city elections and, therefore, threatening supremacy of the native elite. As a result, whiteness emerged as a political battleground for the local Democratic Party. This article seeks to contribute to the evolving scholarship known as "whiteness studies," which seeks to objectify whiteness and makes much more apparent the social construction of a white identity. By tracing voting behavior in Memphis, local politics demonstrates the need to confront race as a power relationship. In Memphis, Irish immigrants and Irish Americans were conflicted between their racial identity of whiteness versus their working class identity as they sought to extend political power garnered during the Civil War and Reconstruction. As a result, white political leaders and the conservative press were forced to consider a new definition of whiteness that included Irish Americans, in order to cement the economic and social dominance of the native, elite white population. Whiteness was politically constructed to the extent it solidified white control versus the abhorrent alternative of black domination and working class solidarity. 1

It is relatively impossible to sever the link between racism and the formation of a white racial identity. I agree with Cornell West who suggests that in order to understand racism one must take a "radically historical" perspective that accounts for a variety of relationships "located in the cultural, political, or even the psychic sphere." Indeed, whiteness studies highlight the dynamic parameters from which self-identities are formed as scholars confront not only race, but also ethnicity and class. David Roediger, in The Wages of Whiteness: Race and the Making of the American Working Class, has elaborated on the complexities of whiteness by suggesting that race and class were interconnected in the social construction of a white identity. For example, W.E.B. Du Bois was one of the first to contemplate on the formation of white skin privilege and speculate on the "psychological wage" whites, especially the working classes, gained from their skin color. As a result, Roediger strives to ascribe the working classes with a central role in the construction of white supremacy. This perspective challenges Marxist historical analysis, which describes racism solely 
in economic terms attributed to capitalist exploitation and class oppression. Instead, historians are encouraged to examine the psychological benefits whites gained from their racial identity. ${ }^{2}$

Because race was malleable it allowed certain ethnic groups to transcend their "otherness" and claim white skin privilege. This became especially important to European immigrants as they sought to assimilate into American culture. The cross-racial alliance, in Memphis, was surprising (at least initially for me) based on the animosity that historically existed between Irish and African Americans. In the South, hostility between the Irish and African Americans existed before the Civil War. For instance, often the labour of a slave was of greater value than that of an unskilled Irish immigrant. It was not uncommon for native whites to define the lrish as "niggers turned inside out" or as "smoked Irish." Central to the creation of a white racial identity was the affirmation of whiteness that separated members of the working classes and ethnic population from slaves and, especially after the Civil War, a free black population. As Irish immigrants searched to construct a place within their new surroundings their status was considerably threatened by their economic standing next to slaves. Therefore, the assimilation of Irish immigrants into American society emphasized the necessity of claiming white skin privilege. ${ }^{3}$ Frederick Douglass noted this racial ambiguity among Irish Americans when he discussed African American civil and political rights:

Perhaps no class of our fellow citizens has carried this prejudice against color to a point more extreme and dangerous than have our Catholic Irish fellow citizens, and yet no people on the face of the earth have been more relentlessly persecuted and oppressed on account of race and religion, than the Irish people. ${ }^{4}$

Nothing embodied this hostility between Irish and African Americans more than the notorious Memphis Massacre. In Memphis, on 1 May, 1866, decommissioned black troops were involved in a confrontation with the city's predominately Irish police force. The incident ignited three days of rioting with the majority of violence directed at the city's new African American migrant population. A Congressional Committee investigated the incident and focused on the "natural hostilities" between Irish and African Americans. Based on the testimony of witnesses it was determined that forty-six African Americans were left dead along with two whites. However, in addition to the murder of innocent civilians, African Americans were raped and robbed and their homes, churches, and schools were burned down. In the end, no white citizens were prosecuted despite the Congressional investigation, and the African American community was forced to rebuild. 5

The Memphis Massacre has been the subject of considerable historical investigation. The majority of scholarship has focused on racial tensions influenced by an influx of African American migrants. Memphis was also a center for the recruitment of black soldiers and the destination for black troops mus- 
tered out after the Civil War. As a result, the Memphis Massacre is understood as a post-war ramification in a social revolution ignited by the emancipation of former slaves. However, Barrington Walker, in the latest interpretation of the Memphis Massacre, suggests the violence was an "ideological" expression of whiteness by an antebellum Irish American community. The burgeoning black migrant population challenged the status of Irish Americans and, as a result, violence emerged as an expedient recourse to claim white skin privilege. ${ }^{6}$

Clearly, the Memphis Massacre was a consequence of an increasing African American population. Memphis fell to federal forces on 9 June, 1862 and a contraband camp was created in the city. Contraband camps were the destination of fugitive slaves and, as a result, the city's African American population grew from 3,882 in 1860 to 15,525 in 1870 . Memphis was also a center for the recruitment of black soldiers. As a result, after the war, Memphis became the residence of a large black migrant population ready to express the promise of their freedom.?

The presence of these newly emancipated blacks unnerved many white Memphians. Elizabeth Meriwether, an affluent resident of Memphis, recognized emancipation as an immediate threat to traditional social relationships. Meriwether, in her memoir, described the changes she encountered following the war:

Next morning on the way into town I saw things which both distressed and alarmed me - blue uniformed negro soldiers swaggering, and sometimes staggering, on the streets; some of these soldiers were playing the gallant to ugly, gaudily dressed negro women. During my walks from one shop to another I sometimes had to get off the sidewalk into the street in order to make way for these negro soldiers - they walked four or five abreast and made not the slightest effort to let white women pass ... Any stranger, seeing those negroes would have supposed the Blacks, not the Whites, were masters in the South. ${ }^{8}$

Meriwether was not the only citizen to express discomfort with armed black soldiers. As early as January 1866, several elite white citizens of Memphis issued an appeal for the removal of black troops. Rumors of a revolt had threatened the stability of the city on Christmas Day, and these white residents favored removing the guns from black soldiers and placing them in the hands of white troops. ${ }^{9}$ Whites were clearly uncomfortable with armed African American soldiers walking their city streets.

However, while the existing literature has focused on the city's increasing black population, Memphis was also the recipient of a large ethnic population before the Civil War. Between the years 1850 and 1860, the German population increased from 470 to 2,042 in the city of Memphis. The Irish population also grew substantially in the decade prior to the Civil War. Four railroads were built between 1850 and 1860 in Memphis, and Irish immigrants filled the need for cheap labour. As a result, the Irish population of Memphis increased from 876 
in 1850 to 5,242 in 1860 . The city was therefore not only divided between black and white, but also by nationality as Memphians confronted the social and political changes of Reconstruction. ${ }^{10}$

As a result of their diminished status, the Irish existed at the bottom of the political hierarchy. The Civil War, however, allowed members of the Irish communities to make inroads in the Memphis municipal government. Dedication to the Confederate cause was severely weakened in the face of defeat. As a result of the Disenfranchisement Act, which was passed in June of 1865 in Tennessee, barring Confederates from political office, many Irish residents were able to elevate themselves to a municipal office. The Disenfranchisement Act was amended in 1866 further restricting the political involvement of exConfederates. By the time of the Memphis massacre, Irish citizens were elected to mayor, recorder, and nine members to the city council. In addition, 163 of the city's 180 Policemen were Irish. ${ }^{1}$ The demographic shift characterized by the preceding decade had finally carved out a space in the political landscape just as the city coped with a new revolution sparked by the emancipation of former slaves.

The Memphis Massacre was a pivotal point in the city's development as it confronted racial and ethnic diversity. In Memphis, minor skirmishes between the police and black soldiers materialized periodically prior to the Memphis Massacre in May of 1866. Black soldiers were an immediate threat to the authority of the predominately Irish police force. African American soldiers were often used to patrol the city streets, placing them in direct contact with the Memphis police. The situation was further intensified when the United States decided to muster-out African American troops. On 30 April, 1866, Irish policemen and African American soldiers were involved in a physical confrontation on the city streets. Events turned worse the following day when police attempted to disperse a large crowd of African Americans in the south section of town for disorderly conduct. A gunfight began, setting off three days of rioting. Rioters directed their violence against the new African American migrant population and symbols of black progress, such as schools and churches, which represented a perceived threat to the newly achieved political status (i.e. "psychological wage") of Irish Americans. ${ }^{12}$

Testimony from local residents in the congressional report revealed the ambiguous nature of whiteness. The investigation focused on the attitudes of local citizens, including the "natural hostility" between Irish and African American residents. Witnesses to the violence consistently noted the Irish character of the mob. The report also uncovered the conflicting social status between the two groups. J. S. Chapin, a local resident, commenting on the citizens of Memphis stated that, "his impression was that a great deal of the people were indifferent to the rioting, for as some said to me, they did not care which whipped [sic], whether the Irish killed off the niggers, or the niggers 
killed off the Irish." H. G. Dent, a businessman in Memphis, went so far as to say that, "the negroes have always felt themselves better than the Irish." Not only did the report shed light on the friction between the Irish and African Americans, but it also embodied an "ideological" battle in definitions of whiteness. ${ }^{13}$

Walker's interpretation of the Memphis Massacre provides an opportunity to examine the historical construction of a white racial identity. However, for many Irish Americans, affirmations of whiteness was a continuous process and the political aftermath that followed the Memphis Massacre revealed a much more ambiguous notion of the "psychological wages of whiteness." As a result, Walker does not adequately account for an ideological struggle that occurred daily. A closer examination of voting behavior reveals that not all Irish Americans solidified the affirmation of a white racial identity during the Memphis Massacre. In fact, members of the Irish American communities debated between their white identity and their working class identity in order to maintain their political dominance in the municipal administration. This also reinforces the need to understand whiteness as a contested reality rooted in the historical circumstance of the political and cultural sphere. Therefore, it should not be surprising that following the Civil War white Memphians recognized Irish Americans "fitness for self-government" just as African Americans were exercising their democratic rights guaranteed by the $13^{\text {th }}, 14^{\text {th }}$, and $15^{\text {th }}$ Amendments. As a result, when confronting racial identities one must account for the larger historical context that oversaw the day-to-day existence of individuals. ${ }^{14}$

Certainly, Reconstruction influenced the political debates that were transpiring in Memphis. In the South, the political upheavals of Reconstruction presented an opportunity to radically transform social relationships. Because of the inability of whites to separate labour in terms of free versus slave, in addition to the reality of poverty solidified by the Civil War, the commonality of white and black labour was reinforced through the creation of party factionalism. Yet, the legacy of Reconstruction and Redemption was the affirmation of white supremacy that limited class solidarity. As a result, the existing historiography focuses primarily on racial conflict and the attempts of white Southerners to maintain social and political continuity. ${ }^{15}$ However, in Memphis, a cross-racial alliance was created from a working class migrant population challenging traditional power relationships. The political initiative in Memphis reinforces the interconnectedness of race, class, and ethnicity. As a result, whiteness was a class and racial identity dependent on political hegemony.

The most radical aspect of Reconstruction was the enfranchisement of African American men. On 26 February, 1867, Governor William Brownlow signed a bill extending voting privileges to African Americans in Tennessee.16 
African Americans embraced their entrance into the political arena and dedicated their loyalty to the Republican Party. African American political agency in the city was embodied in a voting bloc of approximately 2,000 registered voters. The height of success for black voters occurred in the Shelby County elections in the spring of 1868 with a landslide victory for the Republican Party. ${ }^{17}$ However, African Americans did not dominate the local political scene and once Tennessee was redeemed the re-enfranchisement of the white electorate limited the effectiveness of black voters.

An alliance with African Americans was therefore not viewed as politically necessary for Irish Americans, especially while ex-Confederates were still disenfranchised. In Memphis, members of the Irish American communities solidified their position within the Democratic Party in local politics. Native white Memphians were not completely silent on this affair. Dr. William F. Irwin, a practicing physician in Memphis, in the Congressional Report on the Memphis Massacre, testified that, "the voice of respectable people has not been heard; the elections have all been controlled by the Irish." Barbour Lewis, a leader of the Shelby County Republican Party, stated that the city had been "thrown into the hands of the Irish."18 The immediate political concerns for white Memphians after the Civil War was not directed at African Americans, but rather focused on the Irish American communities. A number of Irish Americans were able to gain leverage in the municipal administration and elevate their social status.

One of the city's first critics of this ethnic contingency in municipal politics was the Memphis Daily Post, a Republican newspaper. After the Memphis Massacre the Post led a campaign to eliminate the "corruption" in the municipal government. As the city prepared for the impending city elections of October 1866, the Post editorialized on the deplorable condition of municipal affairs. Memphis, the Post commented, was, "cursed with a city government that we are safe to say surpasses in imbecility and corruption any municipal government in the United States." The Post blamed the immigrant population and, "the custom of Irish voters of Memphis clanning together, and taking into their own hands the entire city government in almost every branch."19

On 15 July, 1868, the Democratic Party was further strengthened when members of the Memphis Jewish community, unsatisfied with the national Republican Party, held a political rally in support of the Democratic Party. "Memphis Jew Joins Forest Democracy," ran the headlines of the Memphis Daily Post ${ }^{20}$ German Americans also supported the local Democratic Party. As a result, Memphis, unlike many cities in the South, did not fall under the control of the Republican Party. Yet, African American voters maintained a strong presence in the electoral arena and pressured the city's ethnic citizens to join the Republican Party.

The first expression of a political alliance between African Americans and 
Irish Americans emerged in the Congressional election in November of 1868. The most heated battle was between William J. Smith and John Leftwich, the current mayor, for Congressman from the eighth district. The Post emphasized the lack of political patronage given to the Irish community by the Democratic Party. Editorials emphasized "the growing feeling of dissatisfaction on the part of the Irish Democrats." On 5 October Republicans held a rally in Memphis displaying banners aimed at the Irish community. "Irish and Negroes should be united for their rights," and "Know-Nothingism is our common enemy," urged Memphis Republicans. Finally, on Election Day the Post printed a letter from Patrick T. Sullivan, an Irish leader, denouncing the Democratic candidate. Sullivan described Leftwich as a man "who is at heart a Know-Nothing and utterly antagonistic to the Irish people." Sullivan went on to characterize Irish support for the Republican Party. Sullivan stated, "I assure you that every Irishman who is devoted to the rights and liberties and interests of his countrymen will cast his vote for the nominee of the Republican Party." Republicans were easily able to elect William J. Smith; however, most likely, the majority of Irish voters were unmoved by the political appeals made by the Republican Party. Voting returns suggest that, in fact, the Democratic and Republican Parties remained relatively consistent despite the focus on the Irish community. ${ }^{21}$

Ironically, despite the emphasis placed on the Irish community, the development of a voting coalition received its most substantial boost from the city's German residents. While German immigrants lacked the strong negative connotations as the Irish, they did contain a powerful voting bloc that demanded political recognition. On 7 February 1870 , a number of German residents in Memphis held a mass meeting forming "a close community society for political purposes feeling that they were slighted in the recent Municipal elections." The Memphis Daily Appeal estimated that over one thousand were present comprising a voting bloc of 848 eligible males. ${ }^{22}$

Why did some German Americans separate themselves from the Democratic Party? Their lack of representation in local politics was most likely a concern, but the previous year had also been a turning point for the state of Tennessee. A race for Governor was highlighted by a public outcry for universal male suffrage and, as a result, a new Constitution was created allowing the re-enfranchisement of ex-Confederates. ${ }^{23}$ As a result, the city's ethnic population lost influence within the Democratic Party. In Memphis, redemption ignited a tumultuous decade characterized by political factionalism as the voting population sought to extend their political influence.

The "German movement" criticized the city's political past. German leaders emphasized their desire to eliminate political parties, which divided the city. There were three groups in the city singled out by German leaders: Confederates, Republicans, and the Irish. A German ticket for county offices 
was established, headed by A. P. Curry for Sheriff. Curry was the radical candidate for Sheriff in the 1868 election that oversaw one of the most unanimous Republican victories in Shelby County. The German union with the Republican Party also included many of the city's Irish residents. Commenting on the strange turn of events, the Memphis Daily Avalanche remarked that, "the colored votes united with the Irish." ${ }^{24}$ Less than five years after the Memphis massacre, African Americans and Irish Americans were united in a political coalition that threatened the dominance of the native white population.

Disgruntled Germans were not the only citizens pushing for the development of a fusion ticket. Leading Republicans recognized the significance of this political coalition and no one was more enthusiastic than Barbour Lewis. Lewis began working with Irishmen John Loague and Pat Riley to strengthen the local Republican Party. Lucien Eaton, in a letter to his brother John Eaton, a couple of days before the county election, wrote, "Lewis is alive with schemes to assist John Loague by electing his deputy Riley." Furthermore, he continued, the most recent political move by Lewis consisted of "fusing the Irish and the negro vote." 25

"Party Lines Bent, Battered, Bruised, Broken, and Busted," rang the headlines of the Memphis Daily Avalanche. The "German movement" had initiated a political coup that effectively defeated the Democratic Party. Recognizing this new political coalition, the Avalanche stated that, "our Irish fellow-citizens struck bands with the Germans and negroes and elected their favorites to office."26 Two days after their success, members of the coalition gathered at Greenlaw Opera House to celebrate their victory. Those present at the meeting included Republican leaders Barbour Lewis, S. B. Beamount, superintendent of the Metropolitan Police, and the Chairman of the Independent German Movement, J. I. Eichberg. But, despite the variety of ethnic groups, the primary focus was on the union between the city's Irish and African American residents. P. J. Mulvihill stated that at last "Irishmen of Memphis had broken the shackles which had so long bound them to the Democratic Party." Edward Shaw emerged as the outspoken African American enthusiast for this new political coalition. Shaw centered his attention on those who criticized him for uniting with the Irish stating "that the colored people would vote the ticket if a hundred Irishmen were on it."27 Increasingly, Irish Americans would find their most beneficial political allies within the African American communities as they struggled to extend their political legacy in Memphis.

The county election was viewed as a success among local Republicans and a source of elevated expectations for its future political survival. The results reflected "a great victory over the Rebs [Rebels] and Democrats," Barbour Lewis wrote to John Eaton. Furthermore, Lewis intended "to keep up the alliance till after our judicial election," and hoped that it might "last much longer." 28 This stands in stark contrast with most cities in the urban South. 
Reconstruction had transformed social relationships, however, the association of the Republican Party nationally with African Americans diminished the possibilities of an alliance with lower class whites. Racism limited black and white interactions. However, in Memphis, ethnicity fueled a cross-racial coalition that challenged the notion of white versus black.

Despite the success of the fusion ticket, German support of the coalition was short lived. One reason may have been that German Americans did not suffer from the same racial biases as Irish and African Americans. German unity still proved a viable factor, but they preferred to coexist within the Democratic Party. German leaders continued to criticize their lack of representation within the Party, but, by the summer of 1871 , it was clear that their support for a fusion ticket was diminishing just as the coalition was beginning to carve out a space for itself in Memphis. On 13 July 1871 the German Democratic Party met and dedicated itself to "conservative principles." Furthermore, they officially pronounced themselves members of the Democratic Party. In a little more than a year, many German voters returned to the Democratic fold, however, this did not mark a return to stability in Memphis politics. ${ }^{29}$

It would be an Irish citizen that added new energy to the political coalition that was rocked by the German departure in the summer of 1871. John Loague arrived in New York City in 1848 from Ireland. Loague eventually made his way south to Memphis in 1860 . Once in Memphis, he was elected to a number of political offices including the school board, tax collector of privileges, and served as a delegate from West Tennessee to the Constitutional Convention of 1865. In the $1870 \mathrm{~s}$, John Loague ran for the mayor's office three times. The cross-racial alliance gained strength under his leadership and eventually elected him as the mayor of Memphis. ${ }^{30}$

Although Irish Americans were integral to the coalition, African Americans and the Republican Party were the primary organizers. In March of 1870 , at the Tennessee Colored Man's Convention, delegates encouraged cooperation with the immigrant population. In Memphis, this became a strong political reality with Loague's campaign for the mayor's office in the municipal election of 1872. As a consequence, white Memphians feared the election would result in a slew of African American elected officials. ${ }^{31}$ However, nothing was more abhorred than Loague's attempt at crossing delicate racial boundaries. Loague was proposing to "put Ireland to bed with Africa" the Appeal commented. White voters were called upon to support the Conservative candidate, John Johnson, or to declare themselves "in favor of Loague and negro councilmen." Yet, Loague also openly challenged white hegemony by promising to integrate the city's police force. Many white Memphians viewed this as a "disgrace" and an issue with which to rally white voters against the city's Irish and African American voters. Conservatives urged that, "if the people of Memphis would prevent the inexplicable chance of seeing negro policemen 
strolling upon their beats, they must give a candid and earnest support to John Johnson." 32

Ethnicity did not supplant race in the campaign but, instead, intensified the battle to affirm a white racial identity. Two days before the municipal election of 1872, the Appeal ran a letter reemphasizing the racial significance of the Irish vote. The letter urged Irishmen to remember that they were "not negroes" and that "the negro is your natural and inevitable enemy and competition in every department of labor." The letter closed with a rather poignant commentary on the nature of this campaign. The writer stated, "Are you the natural friend and ally of the white man or the negro? An Irishman and a negro clasped in each other's arms! God! Of political monstrosities what must be the offspring of such an unholy alliance?" 33 Clearly, white conservatives were drawing racial boundaries as Memphis prepared for the election and Irish Americans were keeping themselves non-white (i.e. "smoky") for political leverage.

In the end, Johnson was elected mayor and Loague's attempt at uniting the ethnic population with African American voters proved unsuccessful. However, Johnson won by less than 1,000 votes. While population schedules do not depict the city's ethnic residents, census data does reveal statistical information by race. In the heavily African American seventh and tenth wards the vote was in Loague's favor. Alexander Dickerson and H. E. Pinn, both African American candidates, were both elected councilmen from the notorious seventh ward. Although Pinn was later disqualified due to residential requirements, Dickerson served out his one-year term. In addition, Edward Shaw managed to garner 1,322 votes in his losing bid for wharf master. ${ }^{34}$ While the coalition was defeated in 1872 , it caused white Memphians to define a racial identity that included Irish Americans.

As the city prepared for the mayoral election of 1874 , the political focus on a common, white identity intensified. The Appeal criticized the politicians for focusing on the city's racial and ethnic character and instead reminded its voters that everyone was an American citizen. This was especially important since John Loague was running again for office. Loague and his "spotted ticket" held meetings at the hall of the Sons of Ham and the Independent PoleBearers, both African American mutual aid societies, in order to drum up African American support. In order to bridge the gap of the city's diverse population, the ticket included an Irishman, a German, and an African American. ${ }^{35}$ The union would open old wounds that had not had time to heal since the Memphis Massacre.

The People's Ticket, largely composed of the city's most affluent white citizens, was created in opposition to Loague and the cross-racial alliance. Citizens that represented the Old Elite were leading a charge to wrestle control away from the city's ethnic and middle class constituents in order to re-establish traditional social relationships. Class divisions ignited a power struggle 
within the local Democratic Party for control of the nomination process. Two years prior, elite citizens lost in the bid for nominating their candidate for mayor. In the municipal election of 1874 , however, the city's "best citizens" nominated J. T. Busby for mayor. The People's Ticket and the conservative press emphasized the animosity between Irish and African Americans that had characterized their relationship in the past. ${ }^{36}$ Nothing was more memorable than the Memphis Massacre, which was remembered as an Irish and African American conflict.

Clearly, the Democratic Party was trying to drive a wedge in between Irish American and African American voters. However, the appeals fell silently on the determination of the coalition to take control of the city administration. Edward Shaw spoke vehemently against this charge denying any validity to the claim. Shaw spoke that it had been stated that, "we [African Americans] were mobbed and our churches burned, and this mob was led by Irishmen." However, in fact, "it was led by one Garrett; an American." While Shaw admitted, "that there were Irishmen in the mob," he also pointed out, "that there were citizens of all classes in the mob." 37 Regardless of how conservatives characterized the violence, the coalition remained intact for the sake of political interest. Despite the race baiting and emphasis on the city's violent past, the coalition witnessed its most substantial victory. Loague was elected as mayor, in addition to four African American councilmen and Edward Shaw as wharfmaster. The Appeal sighed that they were unable "to meet and conquer the opposition," which won with "secret treachery and the union of Irish, German, and negroes." 38

White Memphians, however, reeling from defeat, struggled to affirm a white racial identity that included Irish Americans. In a letter to his brother, John Eaton, Lucien Eaton wrote that, "the old devilish spirit of 1866 has filled the newspaper for the past week." The press, Eaton suggested, was trying, "to incite a riot," and, "unite the whites violently against the blacks." Indeed, for the next several months Memphis would prepare for a County and Congressional election in a racially charged atmosphere. Democrats rallied whites against blacks through a "white man's movement" in order to regain control of the ballot box. The cry for white solidarity was not an uncommon phenomenon in the South as Independent tickets directed their energy against the Democratic Party. White skin, regardless of nationality, became a manner in which Memphis Democrats hoped to wrest control from the coalition. ${ }^{39}$

But, the political campaigns of 1874 were just as much about local autonomy as national outrage. Democrats were beginning to take issue with the proposed Civil Rights Bill that would eventually pass in January of 1875 . J. M. Keating, a resident of Memphis, noted that the Civil Rights Bill reopened old "political sores." This bill was a Republican attempt to extend what little was left of Reconstruction. It extended federal authority in order to protect voters from intimidation. However, one the most controversial measures of the bill for 
white Memphians was the proposed integration of public schools. Edward Shaw's open support of the bill became a central issue for white Conservatives in Memphis as they tried to invigorate white voters against African Americans. The Memphis Daily Appeal claimed that Shaw was ashamed of his own race and attempting to, "enter white society." This was "a colored blunder," they charged, and Shaw did not deserve his office as wharf master. Undoubtedly, the Civil Rights Bill was viewed as an open attack on white society and notions of equality. The "white man's ticket" was therefore a battle to protect traditional values of place, in addition to reasserting power of the native, white elite, and the political involvement of African Americans conflicted with this vision. ${ }^{40}$

The white man's movement, however, was not new, but rather a continuation of political contestation over the definition of whiteness. As a result, the conservative press tried to divide the cross-racial coalition. On 15 July, 1874 the Memphis Daily Appeal reported on a Radial convention, predominantly composed of African Americans, in which its members spoke out against the Irish. It is apparent that Conservatives were keenly aware of the successful cross-racial alliance its Irish and African American residents were able to build. Democrats welcomed its ethnic population in order to, "let every true man with a white skin rally to his color." In the county elections of 6 August 1874, the white ticket won and defeated the African American vote. The Appeal concluded that the results revealed that the Irish were freemen and that, "the white men of all nationalities yesterday made their votes useful." As a result, Democrats celebrated their own alliance composed of white men. ${ }^{41}$

The Congressional election, in November of 1874, was an extension of this "white man's movement," which was aimed at diminishing the leverage of African American voters. Barbour Lewis, Representative from the Eighth Congressional District, was up for reelection in 1874, and white Conservatives rallied against Republican leadership. The Democratic candidate was elected because, the Appeal reported, white people were, "determined to due their duty as citizens." Lewis was defeated by over 2,000 votes. Undoubtedly, this suggests the lack of support by the cross-racial alliance built by Lewis, Loague, and Shaw weakened the impact of the Republican Party. ${ }^{42}$

Redrawing the color line proved to be a successful method for white leadership. However, elite Memphians were also supported by a new alliance between African Americans and the former planter class. On 9 December, 1874, a number of African American benevolent associations declared their support for the city's economic elite..$^{43}$ The "white man's movement" placed African American leaders under continuing scrutiny, however, more importantly, the failure of the Freedmen's Saving and Loan, in addition to the unfulfilled promises issued by Mayor Loague and the national Republican Party, perpetuated this political shift. ${ }^{44}$ As a result, the municipal election of 1875 represented the last gasp of the coalition under Loague's leadership. In the election, the 
Appeal celebrated the success of electing "anti-Loague men" to the General Council. ${ }^{45}$ The apogee of this new political coalition was the elevation of the city's "best citizens" and the election of Mayor John Flippin in the municipal election of 1876.

Despite the success of the city's "best citizens," not all Irish Americans accepted a white racial identity. A Workingman's Party emerged in the municipal election of 1878 reenergizing existing social cleavages. The local Democratic Party was criticized for taking advantage of the city's "poor white men and poor colored men." The Workingmen's candidate was defeated, however, this increased interest in labour embodied the growth nationally of classbased parties. In April of 1878, the Workingmen officially changed their name to the National Party. The Nationalist Party was strengthened in the middle of June when several Irish Democrats split from the local Democratic Party after conflict over the nomination process. As a result, a fusion ticket was created for the impending county elections that summer. The Nationalist Party was successful due to the support of the city's African American and ethnic population. After the election, the Memphis Daily Appeal stated, "the true men of the Democratic Party made a gallant fight, but the tidal wave which swept Radical from Shelby County four years ago has blown backward and the county is under the joint rule the Radicals and the Nationalist." The cross-racial alliance that elevated John Loague to the Mayor's office reemerged with the influence of third party political parties and dissatisfaction among the working classes. ${ }^{46}$

However, the election was a hollow victory for the fusion party. In order to gain control of the city government elite Memphians directed their attention towards political reform. Since the re-enfranchisement of ex-Confederate the city's "best citizens" were involved in a power struggle with city's diverse voting population. They were able to gain control of the local Democratic Party, however, Independent factions limited the influence of the old elite. In 1875, elite reformers, in addition to reevaluating whiteness, formulated a plan to repeal the city's charter and create Commission Government under state control. Elite Memphians organized a tax reform organization aimed at municipal corruption and blamed the voting public stating, "we have in our midst a large and controlling voting element, which has but little at stake in the welfare of our city." In the fall of 1878, a devastating Yellow Fever epidemic ravished the city and turned popular opinion in elite favor. As a result, on 31 January 1879, Memphis officially became the Taxing District of Shelby County. Consequently, state appointed officials and citywide elections guaranteed elite rule and re-established traditional social relationships. ${ }^{47}$

In Memphis, political reform was a medium utilized to silence the initiative of the city's African American, ethnic, and working class population. However, the political battles that transpired in Memphis forced its citizens to re-evaluate and redefine racial identities. Whiteness was publicly debated at the 
ballot box. Voting behavior in Memphis revealed the extent to which representatives from the Irish American communities were conflicted between their white racial identity and their working class identity as political leaders sought to extend their political influence in the city government. As a result, elite Memphians strived to affirm a definition of whiteness that included Irish Americans. But, the formation of a white racial identity was not claimed in a day. Indeed, the political terrain in Memphis reinforces the ideological construction of whiteness that evolved dependent on historical circumstance. Whiteness was and is a power relationship interconnected with race, class, and ethnicity. In order for historians to understand the meaning of whiteness we must continually examine how race was created and recreated on a daily basis. As a result, historians need to develop an inclusive methodology of race that includes a variety of social relationships. Only when we account for the full complexities of racial construction will it be possible to unravel the meaning of white skin privilege.

I The examination of a white racial identity avoids what Barbara Fields has suggested is the tendency to focus on a single race - i.e. black. Instead, historians are encouraged to understand racial classifications as dependent on historical, social, and ideological developments. See Barbara Fields, "Slavery, Race, and Ideology in the United States of America" in New Left Review 181 (May 1990): 95-118. I approach race as a socially constructed category created and recreated daily. Historically, the Irish were not always considered white, but rather a completely separate racial category. As Noel Ignatiev suggests when the Irish arrived in America they often laboured for low wages and lived in abject poverty. Therefore, their life and labor was often compared to free blacks and slaves. To Irish immigrants assimilating into American society emphasized the necessity of claiming white skin privilege. Politics was only one medium used by Irish Americans to define their white racial identity. For a examination of the formation of a white racial identity see the following: Theodore W. Allen, The Invention of the White Race Volume Two: The Origin of Racial Oppression in Anglo America (New York, 1997); Grace Elizabeth Hale, Making Whiteness: The Culture of Segregation in the South, 1890-1940 (New York, 1998); Noel Ignatiev, How the Irish Became White (New York, 1995); Matthew Frye Jacobson, Whiteness of a Different Color: European Immigrants and the Alchemy of Race (Cambridge, 1998); Toni Morrison, Playing in the Dark: Whiteness in the Literary Imagination (New York, 1992); David R. Roediger, The Wages of Whiteness: Race and the Making the American Working Class (New York, 1991, revised, 1999); Alexander Saxton, The Rise and Fall of the White Republic: Class Politics and Mass Culture in Nineteenth Century America (New York, 1990). 
2 Cornell West argues that in order to understand African American oppression one needs to go beyond simplistic Marxists perceptions that view race solely in economic and class terms. See Cornell West, "Race and Social Theory" in The Cornell West Reader (New York, 1999), 251-268. Similarly, David Roediger argues that Marxist analysis privileges class over race and, as a result, white workers are viewed as "dupes," which ignores their role as historical actors. Borrowing from W. E. B. Du Bois, Roediger encourages historians to examine the psychological benefits whites garners from their racial identity. See W. E. B. Du Bois, Black Reconstruction in the United States, 1860-1880 (New York, reprint, 1977); Roediger, The Wages of Whiteness, 6-13. Other scholars have also suggested that race is a separate category experienced independently from class. See George Fredrickson, The Arrogance of Race: Historical Perspective of Slavery, Racism, and Social Inequality (Middletown, 1988); Robin d. g. Kelly, "Looking Forward: How the New Working Class Can Transform America" in Yo' Mama's Disfunktional: Fighting the Culture Wars In Urban America (Boston, 1997).

${ }^{3}$ Ignatiev, How the Irish Became White; Jacobson, Whiteness of a Different Color.

${ }^{4}$ Frederick Douglas, "The Civil Rights Case" in African American Social and Political Thought, 1850-1920. Edited by Howard Brotz with a foreword by B. William Austin (New Brunswick, 1966, reprinted, 1997), 302. Frederick Douglass often made comparisons between African Americans and the Irish. For Douglas, the history of the Irish was important in order to demonstrate the importance of environment and condition in creating race differences. See excerpts from Frederick Douglass in African American Social and Political Thought, 218, 219, 241, 274-276.

${ }^{5}$ As a result of the Memphis Massacre, a Joint Committee Investigation was held providing the most detailed information on the incident in the record of

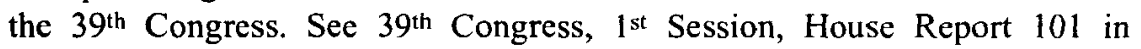
Memphis Riots and Massacres, Mass Violence in America (New York, 1969).

${ }^{6}$ The following were used in relation to this study: Kevin R. Hardwick, "Your Old Father Abe Lincoln is Dead and Damned: Black Soldiers and the Memphis Race Riot of 1866" in The Journal of Social History, 27 (Fall 1993), 109-128; Bobby L. Lovett, "Memphis Riots: White Reaction to Blacks in Memphis, May 1865-June 1866" in Tennessee Historical Quarterly, 38 (Spring 1979), 9-33; Altina L. Waller, "Community, Class and Race in Memphis Riot of 1866" in Journal of Social History, 18 (Winter 1984), 233-246. Barrington Walker, however, utilizes the concept of whiteness as a "psychological wage." See Barrington Walker, "This is the White Man's Day: The Irish, White Racial Identity, and the Memphis Riots of 1866" in Left History, 5 (Fall, 1997), 31-55. ${ }^{7}$ Several Sources were used to develop a historical and demographic perspective of Memphis. See Population Schedules of the $9^{\text {th }}$ Census, 1870, City of 
Memphis, Wards 1-10; Kathleen C. Berkeley, "Like a Plague of Locust: Immigration and Social Change in Memphis, Tennessee," (Ph. D. Dissertation, University of California at Los Angeles, 1980), 111, 125; Gerald Capers, The Biography of a River Town: Its Heroic Age (New Orleans, 1966), 107-8, 163; John Cimprich, Slavery's End in Tennessee, 1861-1865 (Alabama, 1985); Armstead L. Robinson, "Plans Dat Comed from God: Institution Building and the Emergence of Black Leadership in Reconstruction Memphis" in Orville Vernon Burton and Robert C. McMath, Jr., eds., Towards a New South? Studies in Post-Civil War Southern Communities (Westport, 1982), 187; David M. Tucker, Black Pastors and Leaders: Memphis, 1819-1972 (Memphis, 1975), 57.

${ }^{8}$ Elizabeth A. Meriwether, Recollections of 92 Years, 1824-1916 (Nashville, 1958), 164-167.

${ }^{9}$ Memphis Daily Post, 28 January, 1866, 4.

${ }^{10}$ The urban South received a large influx of ethnic immigrants before the Civil War. New Orleans contained a large ethnic population along with such cities as Charleston, Mobile, and Nashville. Ira Berlin and Herbert B. Gutman have encouraged historians to examine the implications of ethnicity on the antebellum South. Ira Berlin and Herbert G. Gutman, "Natives and Immigrants, Free Men and Slaves: Urban Workingmen in the Antebellum South" in The American Historical Review, 88 (December, 1983): 1175-1200. However, as a result of the Civil War and the emancipation of former slaves, historians have concluded ethnicity and class were submerged beneath racial tensions. See David R. Goldfield, Cotton Fields and Skyscrapers: Southern City and Region (Baltimore, 1982). Yet, Kathleen Berkeley has suggested that in Memphis the "ethnic question" was not submerged beneath the "race question" and, as a result, historians need to reexamine the implications of ethnicity in the urban South. See Kathleen C. Berkeley, "Ethnicity and Its Implications for Southern Urban History: The Saga of Memphis, Tennessee, 1850-1880," Tennessee Historical Quarterly, 50 (Winter 1991): 193-202. For a detailed examination on European immigration and demographics in Memphis see Berkeley, "Like a Plague of Locust," 1-28, 125-149; William B. Stanton, "The Irish of Memphis" in West Tennessee Historical Society Papers, 4 (1950), 72-82.

11 Thomas Alexander, Political Reconstruction in Tennessee (Nashville, 1950), 38; Berkeley, "Ethnicity and Its Implications for Southern Urban History," 193202; DeeGee Lester, "Tennessee Bold Fenian Men," Tennessee Historical Quarterly, 56 (Winter, 1997), 262-277; Memphis Riots and Massacres, 23.

12 Memphis Riots and Massacres, 4-36; Memphis Daily Appeal, 1 May, 1866; 2 May, 1866; 3 May, 1866; Memphis Daily Post, 29 April, 1866, 8; 1 May, $1866,8$.

${ }^{13}$ Memphis Riots and Massacres, 192-197, 306. Barrington Walker uses these accounts to demonstrate how Irish Americans used the Memphis Massacre as 
an attempt to claim a white racial identity. See Walker, "This is a White Man's Day," 31-55.

${ }^{14}$ Barbara Fields suggests that, "ideology is best understood as the descriptive vocabulary of day-to-day existence, through which people make rough sense of the social reality that they live and create from day to day." As a result, the Memphis Massacre is only one struggle in a continuous contest in the claiming of white skin privilege. See Fields, "Slavery, Race, and Ideology in the United States of America," 110. But, in addition, in order to understand race historically, we have to examine the larger societal context that frames these daily struggles. This dual existence is what Thomas Holt defines as "the levels problem." Specifically, "the problem of establishing the continuity between behavioral explanations sited at the individual level of human experience and those at the level of society and social forces." See Thomas C. Holt, "Marking: Race, Race-making, and the Writing of History" in The American Historical Review 100, Issue I (February 1995), 7. Matthew Frye Jacobson contends that while historians such as Theodore W. Allen and David R. Roediger have emphasized the economic characteristics of a racial identity, whiteness was rooted in a political culture of republicanism dependent on nation building and "fitness for self-government." Jacobson, Whiteness of a Different Color, 17-20. In Memphis, the enfranchisement of African Americans was influential in the redefinition of a white racial identity that included Irish Americans as politically viable for "self-government."

15 Eric Foner has emphasized the need to approach Reconstruction as a social, political and economic revolution. See Eric Foner, Reconstruction: America's Unfinished Revolution, 1863-1877 (New York, 1988). For an examination on the volatility of race and class during Reconstruction and its aftermath the following were used in relation to this article: Michael W. Fitzgerald, "Radical Republicanism and the White Yeomanry During Alabama Reconstruction, 1865-68," Journal of Southern History, 54 (1988), 565-96; Goldfield, Cotton Fields and Sky Scrappers; Joy J. Jackson, New Orleans in the Gilded Age: Politics and Urban Progress, 1880-1896 (Louisiana, 1969); V. O. Key, Southern Politics (1949); Albert D. Kirwan, Revolt of the Rednecks: Mississippi Politics, 1876-1925 (Lexington, 1951); Roger W. Shugg, Origins of Class Struggle in Louisiana: A Social History of White Farmers and Laborers During and After, 1840-1875 (Louisiana, 1939, reprint, 1966); Kenneth M. Stampp, The Era of Reconstruction, 1865-1877 (New York, 1965); C. Vann Woodward, Origins of the New South, 1877-1913 (Louisiana, 1951); C. Vann Woodward, The Strange Career of Jim Crow; Charles E. Wynes, Race Relations in Virginia, 1870-1902 (Charlottesville, 1961).

16 Alexander, Political Reconstruction in Tennessee, 101-154; William Gillespie McBride, "Blacks and the Race Issues in Tennessee Politics," (Ph. D. Dissertation, Vanderbilt University, 1989), 168-171. 
17 Memphis Daily Post, 17 March, 1868, 4. Kathleen Berkeley concludes the African American vote was "uncommitted" and "materialized." See Berkeley, "Ethnicity and Its Implications for Southern Urban History," 191-202. However, an overwhelming majority of African American voters dedicated themselves to the Republican Party, representing a voting constituency of roughly 2,000 voters. See Brian D. Page, "The Silent Whisper of Redemption: African American Agency, Voting Coalitions, and the Repeal of the Memphis City Charter, 1865-1879," (M.A. Thesis, University of Memphis, 2000), 35-62. 18 Memphis Riots and Massacres, 132; Walker, "This is the White Man's Day," 47.

${ }_{19}$ Memphis Daily Post, 4 October, 1866, 6 October 1866, 4.

20 Memphis Daily Post, 16 July, 1868, 4; Berkeley, "Ethnicity and Its Implications for Southern Urban History," 193.

${ }^{21}$ Memphis Daily Post, 6 October, 1868; 2 November, 1868; Berkeley, "Ethnicity and Its Implications for Southern Urban History," 195. Despite the political appeals made by the Republican Party towards the Irish, the Democratic vote actually increased by 110 voters in comparison with the previous municipal election. See Memphis Daily Post, 2 January, 1868, 8; 4 November, 1868, 1, 4. While Kathleen Berkeley agrees that the Democratic Party remained consistent she argues the African American vote "materialized" for the Congressional election. Berkeley, "Ethnicity and Its Implications for Southern Urban History," 195. However, Republican totals remained consistent with the previous election that spring. See Memphis Daily Post, 9 March, 1868, 1.

${ }^{22}$ Memphis Daily Appeal, 8 February, 1870, 4; 10 February, 1870, 4.

23 Alexander, Political Reconstruction in Tennessee, 199-233; McBride, "Blacks and the Race Issue in Tennessee Politics," 290-344.

24 Memphis Daily Appeal, 10 February, 1870, 4; 12 February, 1870, 4; Memphis Daily Avalanche, 25 March, 1870, 3; 13 March, 1870, 3; 27 March, $1870,2$.

${ }^{25}$ Lucien Eaton to John Eaton, 21 March, 1870, in the John Eaton Papers, Special Collections, the University of Tennessee Library, Knoxville.

${ }^{26}$ Memphis Daily Avalanche 27 March, 1870, 3.

27 Ibid., 29 March, 1870, 3.

${ }^{28}$ Barbour Lewis to John Eaton, 29 March, 1870, in the John Eaton Papers.

29 Memphis Daily Avalanche, 15 July, 1870, 4; 14 July, 1871, 4.

${ }^{30} \mathrm{O}$. F. Vedder, History of the City of Memphis and Shelby County, Tennessee (Syracuse, 1888), 153-54.

31 McBride, "Blacks and the Race Issue in Tennessee," 345-349. Kathleen Berkeley argues that ethnicity supplanted race in Memphis politics, while African American voters were "uncommitted" and pawns of the Irish electorate. See Berkeley, "Ethnicity and Its Implications for Southern Urban 
History," 193-202. However, African Americans were active in the creation of the cross-racial coalition. Furthermore, race was never absent in local politics rather ethnicity energized racial animosity as white Memphians struggled to affirm a white racial identity. The white press feared a large black electorate would result in the election of African American political officials. See Memphis Daily Appeal, 24 August, 1871, 4, 16 December, 1871, 4.

32 Memphis Daily Appeal, 16 December, 1871, 4; 17 December, 1871, 4; 22 December, 1871, 4, 31 December, 1871, 2, 4; 1 January, 1872, 2; 3 January, 1872, 2; 4 January, 1872, 2.

33 Ibid., 2 January, 1872, 4.

34 Ibid., 6 January, 1872, 4. Joe Walk has done a detailed examination of African Americans in Memphis that were elected to political office. See Joe Walk, "A History of African Americans in Memphis Government," (Memphis, nd.).

35 Memphis Daily Appeal, 30 November, 1873, 2; 3 December, 1873, 4; 5 December, 1873, 2; Memphis Daily Avalanche, 4 December, 1873; 9 December, 1873.

${ }^{36}$ Kathleen Berkeley contends Reconstruction propelled a "middle class revolution" in the Memphis city government. As a result, members of the old elite orchestrated a political coup by influencing the city and the state government to except a plan repealing the Memphis city charter. See Berkeley, "Like a Plague of Locust." Lynette Boney Wrenn has most recently reinforced this theory of urban redemption in her detailed examination of elite rule. See Boney Wrenn, Crises and Commission Government: Elite Rule During the Gilded Age (Knoxville, 1998). However, the power struggle between elite Memphians and their middle class constituents transpired within the nomination process of the Democratic Party. See Memphis Daily Appeal, 12 November, 1871, 1; 30 November, 1871, 2, 3; 3 December, 1871, 4; 6 December, 1871, 1; 25 November, 1873, 4; 27 November, 1873, 1.

37 Memphis Daily Avalanche, 10 December, 1873; 18 December, 1873.

38 Memphis Daily Appeal, 10 December, 1873, 2; 13 December, 1873, 4; 2 January, 1874, 4; 3 January, 1874, 4; Walk, "A History of African Americans in Memphis Government," 6-8, 18.

39 Lucien Eaton to John Eaton, 7 June, 1874, in the John Eaton Papers; Memphis Daily Appeal, 15 February, 1874, 1; 22 July, 1874, 2; 28 July, 1874, $4 ; 1$ August, 1874, 4; 6 August, 1874, 1; 7 August, 1874, 2. The call for white solidarity was most pronounced in the face of class divisions and white supremacy was used to diminish political dissent. See Goldfield, Cotton Fields and Skyscrapers, 108; Kirwan, Revolt of the Rednecks, 24, 308-09; Woodward, Origins of the New South, 105; Charles E. Wynes, Race Relations in Virginia, $10,144-46$.

40 Memphis Daily Appeal, 6 May, 1874, 1; 9 May, 1874, 2; 7 July, 1874, 2; 15 
July, 1874, 1; Keating, History of the City of Memphis and Shelby County, 626. For more information of the Civil Rights Bill see Foner, Reconstruction, 553$556,587$.

${ }^{41}$ Memphis Daily Appeal, 15 July, 1874, 1; 22 July, 1874, 2; 7 August, 1874, 2.

42 Ibid., 4 November, 1874, 1.

${ }^{43}$ Memphis Daily Appeal, 9 December, 1874, 4.

44 National attention on a Civil Rights Bill intensified white criticisms of African American political leaders. Yet, dissatisfaction with the Republican Party was more of an immediate concern among black voters. See Memphis Daily Appeal, 31 May, 1874, 1; 6 June, 1874, 4; 9 June, 1874, 1; 12 June, 1874, 2; 4 April, 1874, 4; 23 December, 1874, 4; 11 January, 1876, 4; But, Beverly G. Bond suggests that, in actuality, the alliance between former slaves and the planter class was due to a battle for self-determination among African Americans. Many members of the antebellum free black community supported northern missionaries versus the new migrant population who did not share the same sentiments. These divisions in the black community emerged in a controversy between Sarah Thompson, an African American teacher, and J. H. Barnum, a principal of a local black school. Both the new migrant population and the old elite supported Sarah Thompson. As a result, the alliance between African Americans and the former planter class was mutually beneficial. African Americans continued their cause for self-determination while white conservatives criticized outsiders. See Beverly G. Bond, Troublesome Times: African American Women in Memphis, Tennessee, 1820-1905 (unpublished manuscript), 193-208.

45 Ibid., 8 January, 1875.

46 Memphis Daily Appeal, 11 December, 1877, 2; 12 December, 1877, 4; 13 December, 1877, 4; 19 December, 1877, 4; 28 December, 1877, 4; 28 April, 1878,4 ; 14 June, 1878, 4; 18 June, 1878, 4; 20 June, 1878; 23 June, 1878, 4; 28 June, 1878, 1, 4; 2 August, 1878, $2,4$.

47 Memphis Daily Appeal, 12 January, 1875, 4; 1 November, 1878; 2 November, 1878; 10 November, 1878 ; 14 January, 1879 . For a detailed examination of the elite reform movement see Wrenn, Crises and Commission Government. Memphis, however, was not the only southern city to initiate political reform as a medium to curtail ward politicians and working class agency. See Don H. Doyle, Nashville in the New South, 1880-1930 (Knoxville, 1985); Carl Vernon Harris, Political Power in Birmingham, 1871-1921 (Knoxville, 1977); Jackson, New Orleans in the Gilded Age; James M. Russell, "Elites and Municipal Politics and Government in Atlanta, 1847-1890" in Burton and McMath, eds., Toward A New South? Studies in Post-Civil War Southern Communities, 37-70. 